\title{
ÁTÉPÍTÉS
}

\section{KÖZIGAZGATÁS-TERÜLETFEJLESZTÉS- VÁROSMARKETING}

\author{
BESZTERI BÉLA
}

A fenti címmel jelent meg a Comitatusban, a Megyei Önkormányzatok Országos Szövetségének folyóiratában 1994-1996 között publikált cikkekböl és tanulmányokból, valamint a folyóirat köré szerveződött kutatócsoport zárótanulmányaiból készült válogatás.

Elözménye $A$ lebegő megye címü tanulmány- és cikkgyüjtemény a folyóirat Veszprém megyei szerzőinek 1991-93 közötti írásaiból és a Comitatus kutatócsoport munkáiból. Mindkét kőtet a Veszprém Megyei Önkormányzat Közigazgatási és Informatikai Szolgáltató Irodája adta ki, szerkesztője Agg Zoltán volt.

Az Átépités címü gyüjtemény a Megyei Önkormányzatok Országos Szövetségének alkotó hozzájárulása volt a magyar honfoglalás 1100 . évfordulójához. Az újabb kötet szerzői köre is jelentösen bövült: veszprémi, budapesti, győri és pécsi szakemberek és kutatók munkáit egyaránt olvashatjuk a gyüjteményben.

A kötet elsö lapjain - szerkesztői cikkek alapján - képet kaphat az olvasó a Comitatus céljairól és problémáiról. A comitatus latin szó, magyar jelentése a megye. A folyóiratra a megyei öntudat és a megyei önazonosság (identitás) erősitése miatt van szükség. Fontos szerepe van a lapnak a politikai döntéshozók befolyásolásában. A Comitatus Önkormányzati Szemle a megyék létét megkérdőjelező politikai támadások ellenhatásaként szervezödött. A megyei önkormányzatokra szükség van. Átfogó megyehatár rendezésre egyhamar aligha kerülhet sor. Megszüntetni valamit, ami müködik, létrehozni helyette valami egészen új rendszert, ami felforgatná nemcsak a közigazgatási, hanem a társadalmi viszonyokat és ezáltal a lakossági életfeltételeket, aligha van önkormányzat, amely ezt megkísérelné megtenni.

Az elmúlt évek termése és a recenzált kötet is bizonyítja, hogy az Önkormányzati Szemle nem zárkózott be a megyekutatás elefántcsonttornyába.

Megvalósult gyakorlata, hogy fórumot ad az egymásnak mellérendelt önkormányzatoknak. Szakmai publikációs fórumot teremtett a megyei és a regionális kutatások ösztönzésére. Katalizátor szerepet tölt be a regionális és a területfejlesztési kérdések iránt érdeklődő szakem jerek és kutatók között.

Ezen céloktól vezérelve, a gyüjteménye elsö fejezete elméleti kérdéseket tárgyal. Maradandó értékü tanulmányok találhatók e részben a megye feladatai és hatáskörök alakulásától (Zongor Gábor), a közigazgatás, a hatalom és kormányzás 
forgalmi meghatározásáról és történelmi változásairól (Agg Zoltán), az önkormányzatok és a területfejlesztés alulnézetböl történö vizsgálatáról (Horváth László), a lágy és kúszó környezeti katasztrófák ökológiájáról (Csalogovits István) és a területi érdekképviseletről a Kádár-korszakban (Navracsics Tibor).

A következő fejezetben interjúk olvashatók Kunce Gábor belügyminiszterrel, Vastagh Pál igazságügy-miniszterrrel, Naszvadi György és Kara Pál helyettes államtitkárral. Az első beszélgetés az ơnkormányzati törvény módosításáról, ezen belül a középszintủ irányításról szól. $\mathrm{Az}$ igazságủgy-miniszterrel az alkotmányozásról és az önkormányzatiságról, a Pénzügyminisztérium helyettes államtitkárával az államháztartási reformról, a belügyminisztériumi főtisztviselővel a megyék jövőjéről folytattak eszmecserét a lap vezető munkatársai.

A Megyekutatás címủ fejezetben Északnyugat-Dunántúl politikai atlaszát vázolta fel Oláh Miklós kitünő, a tárgykörben hézagpótló tanulmánya. A szerző történeti analízist és a rendszerváltás utáni választási elemzéseket elvégezve arra a következtetésre jutott helyesen, hogy a régió politikai arculatát az átlagost jóval meghaladó politikai aktivitás, a választópolgárok politikai ideológiák mentén tapasztalható viszonylagos kiegyensúlyozottsága és a szélsőségektöl való mentessége jellemzi. Mindezek alapján a térség az országon belül is kiegyensúlyozott szerepet tölt be. A Vita c. rovatban Pálné Kovács Ilona (Rekviem a tetszhalott megyékért) úgy értékelte, hogy a rendszerváltás óta a megyevita politikai kérdéssé vált, mintha annak eldöntése csupán pártpolitikai programok vagy személyiségek mindenkori erőviszonyainak függvénye lenne. A kialakult helyzetet meglehetősen elkeserítőnek ítélte: "A megyei önkormányzatok tényleges feladatokhoz és hatáskőrökhöz jutásának reménye fényévnyi távolságra került a területfejlesztési törvény és a területi államigazgatási rendszercsomag elfogadásával. (164. o.) Zongor Gábor is meglehetősen lehangoló helyzetképről számol be: "A tervszerüen is végig nem gondolt állami aknásítási folyamat eredményeképpen a megyei önkormányzat döglött aknává vált. Félö azonban, hogy a döglőtt akna felrobban." (181. o.) A megyerendszer létjogosultságát megkérdójelezó vélemények tarthatatlanságát Agg Zoltán okos érveléssel kérdőjelezi meg, amikor arra hivatkozik "Megy-e vagy marad" címủ vitairatában, hogy más és más a termelés, a szolgáltatás és a közigazgatás természete: nem arra kell tërekedni, hogy a közigazgatási határokat a gyakran változó gazdasági, ellátási körzetekhez igazítsuk, hanem arra van szlikség, hogy a közigazgatási határok nem akadályozzák a gazdasági és a társadalmi folyamatok célszerủ kibontakozását. Nem lehet eltekinteni az állampolgárok érdekeitöl sem, hiszen a távolabb kerülö megyeszékhelyek szinte elháríthatatlan nehézségeket okoznának ügyeik intézésekor. De az sem lenne megoldás - érvel a szerző -, ha visszaállítanák a korábbi járásoknak megfelelő kistérségi közigazgatási rendszert, mert annak hatalmas költségei súlyos terheket okoznának az állami költségvetésnek.

Az egyik legigényesebb fejezet az „Országos kutatások” címet viselö rész. "A helyi elit szerepe a kelet-kőzép-európai új demokráciák önkormányzati életében." 
címü tanulmány, Oláh Miklós munkája, a japán Hokkaido Egyetem és a Megyei Önkormányzatok Országos Szövetségének megrendelésére készült 1996 tavaszán. Jelen tanulmány elsö közlés a kutatások eredményéröl. Az anyag japán nyelvü változata pedig most van megjelenés alatt. A nemzetközi érdeklödésre is számottartó kutatás azért jelentös, mert a szerző hiánypótló vizsgálatot folytatott. A kelet-közép-európai rendszerváltásról a struktúraváltozásokról szóló kutatások alapvető hiányossága, hogy a makroszintü kutatásokon túl nem folytattak vizsgálatokat a vidék gazdasági és társadalmi életéröl, a helyi társadalmakról, a helyi hatalmi viszonyokról. Az elit kutatások pedig többnyire a gazdasági élet csúcsát célozták meg. A helyi elit vizsgálatát - kérdőíves szociológiai módszerrel - a helyi társadalomba, a települések és önkormányzatok életének egészébe ágyazottan végezte el Oláh Miklós, és az újszerü vizsgálat jelentösen gazdagította a helyi társadalom és a helyi elit szakirodalmát.

Rendkívül értékes a gyakorlati hasznosíthatóság szempontjából Nemes Nagy Józsefnek a "Városok a piacgazdasági átmenetben" címü elemzése, amely az aktuális gazdasági dinamikaelemek, illetve a válságjegyek alapján tárja fel 199 vidéki város helyzetét és állítja rangsorba őket. Budapest kiemelkedö szerepe minden dimenzióban és mutatószámban teljesen egyértelmü. Az elemzés három faktort vizsgált: a munkavállalói, a vállalkozói és a külföldi töke terét. A kutatás eredményeképpen a 199 vidéki város a 3 rangszám összegének növekvő sorrendjében helyezkedik el. A kedvezö helyzetü városok között egyaránt megtalálhatók nagyobb regionális centrumok és kisebb dinamikus központok. A nyugati fekvés minden vizsgált tényező alapján előnytényezö. A legjobb összpozícióban Sopron, Szentendre és Budaőrs áll. Érthető, hogy Nemes Nagy József vizsgálatára és közölt várossorrendi táblázatára a parlamenti viták során is hivatkoztak egyes hozzászólók.

A „Vảrosmarketing” címủ fejezetben található a Comitatus 1995. évi nívódiját elnyert tanulmány. Probáld Katalin Városmarketing címü irása méltán szolgált rá a kiemelkedő elismerésre. Kitủnő a téma elméleti megalapozása, a nyugati városmarketingröl szóló megközelítések és értelmezések kritikai bemutatása. Gazdag szakirodalmi leírást és néhány európai városban személyesen megismert marketing stratégiát ajánl és vet egybe a hazai gyakorlattal. Ismerteti a beruházók és befektetők mérlegelési szempontjait, a turisztikai vonzástényezők átfogó rendszerét. Probáld Katalin úgy összegzi kutatási tapasztalatait, hogy rámutat: a városmarketing merőben új szemléletmódot jelent. Ez a várostervezőktől és az önkormányzatoktól a képzelőerő, az intuíció, a szervezőkészség és a határozottság sajátos kombinációját követeli meg. A hazai önkormányzatoknak e téren még sok a tennivalójuk, sok tapasztalatot kell még szerezniük. A városmarketingnek ugyanis a piacgazdaságra való áttérés és a külföldi felé nyitás jelen szakaszában különösen nagy a jelentősége, ezért igencsak időszerủ feladat a témára vonatkozó ismeretek összefoglalása, megvalósítása és elterjesztése. 
A Comitatus Önkormányzati Szemle cikkei országos rangot szereztek a folyóiratnak a széles szakmai közvéleményben, s a lap köré szerveződött mühely szerzö az évek során országosan ismertekké és elismertekké váltak. Ennek kifejezője, hogy a publikált tanulmányokból, kutatási eredményekből rendszeresen tallózik a Kossuth Rádió Szemle címü müsora, továbbá erről tanúskodnak az olvasók méltató sorai. A kötet egyetemi segédanyag, minthogy az írások elméleti igényessége, tudományos megalapozottsága és hasznosíthatósága külön is felkelti mint az oktatók, mint a leendó szakemberek (ma még hallgatók) figyelmét. A könyv a legidószerübb témákat vizsgálja és ütközteti a tudományos irodalom és a szakemberek tapasztalatait. A témák egy része beépült az MTA Regionális Kutatások Központja Nyugat-Dunántúli Tudományos Intézetének kutatási programjába is. Hiányérzetünk van azonban a kötet szerzőinek bemutatása miatt.

A gyüjteményes kötet hatalmas szellemi kincs, kutatási eredmények és tapasztalatok tárháza. Egyaránt haszonnal forgathatják a könyvet a megyei kőzgyülések tagjai és tisztségviselöi, a városok és községek polgármesterei; az önkormányzati hivatalok vezetői és munkatársai; az országgyưlési képviselök; a közigazgatási, regionális, társadalompolitikai, geográfus, szociológus, közgazdász szakma tudományos mủvelöi, irányitói, valamint a kötetben szereplö témák iránt érdeklődők. 